\title{
PENGEMBANGAN MODEL PEMBELAJARAN KOOPERATIF TIPE TAI TERHADAP HASIL BELAJAR SISWA MATA PELAJARAN IPS
}

\author{
Restu Wibawa \\ Program Studi Teknologi Pendidikan FIP IKIP Mataram \\ email korespondensi : restuwibawa@ikipmataram.ac.id
}

\begin{abstract}
Abstrak. SDN 7 Kediri berada di wilayah Kabupaten Lombok Barat Nusa Tenggara Barat, dalam proses pembelajaran masih mengutamakan kemampuan akademik dan metode pembelajaran yang digunakan belum variatif. Pembelajaran IPS disekolah selalu disajikan dalam bentuk faktual, konsep yang kering, guru hanya mengejar target pencapaian kurikulum, tidak mementingkan proses, karena itu pembelajaran IPS selalu menjenuhkan dan membosankan, dan oleh siswa dianggap sebagai pelajaran kelas dua, sehingga siswa tidak tidak memenuhi KKM (Kriteria Ketuntasan Mengajar). Kesulitan itu dikarenakan siswa bukan hanya sebagai individu dengan segala keunikannya, tetapi siswa juga sebagai makhluk sosial dengan latar belakang yang berbeda. Sebagai profesi, kemampuan menjadi guru membutuhkan kriteria khusus seperti penguasaan ilmu, seni dan keterampilan. Ilmu pengetahuan tentang dasar-dasar keguruan dan materi bidang studi sangat perlu dikuasai oleh guru agar dalam melaksanakan tugasnya dapat menjadi guru yang baik dan profesional. Penggunaan model yang baik oleh guru adalah model yang bisa mengkondisikan siswa dalam proses pembelajaran. Sehingga dalam menggunakan model guru harus memilih yang sesuai dengan materi yang diajarkan dalam proses pembelajaran di kelas. Model yang dimaksud adalah model pembelajaran Kooperatif Tipe TAI untuk meningkatkan hasil belajar siswa pada Mata pelajaran IPS. Metode Kooperatif Tipe TAI ini tipe pembelajaran yang membentuk kelompok kecil yang heterogen dengan latar belakang cara berpikir yang berbeda untuk saling membantu terhadap siswa lain yang membutuhkan bantuan. Dalam tipe ini, diterapkan bimbingan antar teman, yaitu siswa yang pandai bertanggung jawab kepada siswa yang lemah. Karena keberhasilan dari tiap individu ditentukan oleh keberhasilan kelompok. Dalam pelaksanaan penelitian ini menggunakan metode Research and Development. 10 tahap diantaranya (1) Potensi dan Masalah, (2) Pengumpulan Data, (3) Desain Produk, (4) Validasi Desain, (5) Revisi Desain, (6) Ujicoba Produk, (7) Revisi Desain, (8) Ujicoba Pemakaian, (9) Revisi Produk, (10) Produk Akhir. Instrumen yang digunakan adalah angket, tes, dan pedoman wawancara. Penelitian ini dilakukan dengan tiga tahapan ujicoba yaitu ujicoba terbatas, ujicoba lapangan, dan ujicoba produk operasional. Teknik analisis data menggunakan uji hipotesis $t$-test.
\end{abstract}

\section{Kata kunci: Kooperatif Tipe TAI, Hasil Belajar Siswa}

\begin{abstract}
SDN 7 Kediri is located in West Lombok Regency, West Nusa Tenggara, in the learning process it still prioritizes academic ability and the learning methods used have not been varied. Social studies learning in schools is always presented in a factual, dry concept, teachers only pursue curriculum achievement targets, do not attach importance to the process, therefore social studies learning is always saturated and boring, and by students it is considered a second grade lesson, so that students do not meet the KKM (Criteria Teaching Completeness). The difficulty is because students are not only individuals with all their uniqueness, but students are also social beings with different backgrounds. As a profession, the ability to become a teacher requires specific criteria such as mastery of science, arts and skills. Teachers need to master knowledge of the basics of teacher training and subject matter so that they can become good and professional teachers in carrying out their duties. The use of a good model by the teacher is a model that can condition students in the learning process. So that in using the model the teacher must choose what is in accordance with the material taught in the learning process in the classroom. The model in question is the Type Tai Cooperative learning model to improve student learning outcomes in social studies subjects. The Tai Type Cooperative Method is a type of learning that forms small, heterogeneous groups with different thinking backgrounds to help each other towards other students who need help. In this type, guidance is applied between friends, namely students who are good at being responsible for weak students. Because the success of each individual is determined by the success of the group. In the implementation of this study using the Research and Development method. The 10 stages include (1) Potential and Problems, (2) Data Collection, (3) Product Design, (4) Design
\end{abstract}


Validation, (5) Design Revision, (6) Product Testing, (7) Design Revision, (8) Testing Usage, (9) Product Revision, (10) End Product. The instruments used were questionnaires, tests, and interview guides. This research was conducted in three stages of testing, namely limited trials, field trials, and operational product trials. The data analysis technique used the t-test hypothesis test. 


\section{PENDAHULUAN}

Belajar sejatinya merupakan proses yang dilakukan sepanjang hidup manusia. Cronbach dalam Djamarah (2008:13) berpendapat bahwa belajar sebagai "suatu aktivitas yang ditunjukan oleh perubahan tingkah laku sebagai hasil dari pengalaman". Walaupun belajar berjalan seiring dengan berjalannya proses kehidupan, namun prosesnya tidak tercipta begitu saja, melainkan memerlukan kondisi yang dibentuk secara sengaja. Proses belajar mengajar yang dilakukan secara formal sering kali masih menggunakan format lama. Format lama yang dimaksud adalah cara-cara mengajar konvensional yang lebih berpusat pada guru (teacher-centered). Pada teori tabula rasa John Locke dalam Anita Lie (2002:2) menyatakan "bahwa pikiran seorang anak adalah seperti kertas kosong yang putih bersih dan siap menunggu coretan-coretan gurunya”. Dengan kata lain, otak seorang anak adalah ibarat botol kosong yang siap diisi dengan segala ilmu pengetahuan dan kebijaksanaan guru. Dengan pandangan seperti ini banyak guru yang masih menjalankan proses belajar mengajar dengan berorientasi pada penyampaian materi saja. Hal ini tentu saja berpengaruh pada hasil belajar siswa, termaksud pada mata pelajaran

Berdasarkan hasil wawancara dengan beberapa guru SDN 7 Kediri menyatakan bahwa sebagian besar siswa masih mengalami masalah dalam penbelajaran IPS sehingga sebagian besar siswa tidak memenuhi KKM . Mata pelajaran IPS merupakan seleksi dari disiplin ilmu-ilmu sosial dan humaniora, serta kegiatan dasar manusia yang diorganisasikan dan disajikan secara ilmiah dan psikolgis untuk tujuan pendidikan. (Sapriya : 2009). Adapun tipe TAI (Team Assited Individualization ) adalah tipe pembelajaran yang membentuk kelompok kecil yang heterogen dengan latar belakang cara berpikir yang berbeda untuk saling membantu terhadap siswa lain yang membutuhkan bantuan. Dalam tipe ini, diterapkan bimbingan antar teman, yaitu siswa yang pandai bertanggung jawab kepada siswa yang lemah. Karena keberhasilan dari tiap individu ditentukan oleh keberhasilan kelompok.

Pembelajaran kooperatif tipe TAI ini dikembangkan oleh Slavin. Tipe ini mengkombinasikan keunggulan pembelajaran kooperatif dan pembelajaran idnidvidual. Tipe ini 
dirancang untuk mengatasi kesulitan belajar siswa secara individual. Oleh karena itu, kegiatan pembelajarannya lebih banyak digunakan untuk pemecahan masalah, ciri khas pada tipe TAI ini adalah setiap siswa secara individual belajar materi pembelajaran yang sudah dipersiapkan oleh guru. Hasil belajar individual dibawa ke kelompok-kelompok untuk didiskusikan dan saling dibahas oleh anggota kelompok, dan semua anggota kelompok bertanggung jawab atas keseluruhan jawaban sebagai tanggung jawab bersama. Setiap pembelajaran harus menimbulkan minat kepada peserta didik untuk menghasilkan sesuatu atau dapat menyelesaikan suatu masalah dengan menggunakan metode, teknik atau cara yang dikuasai oleh siswa itu sendiri yang diperoleh dari proses pembelajaran. Dengan demikian metode pembelajaran TAI (Team Assited Individualization merupakan model yang sangat penting yang perlu di terapkan oleh guru, agar tujuan pembelajaran dapat berhasil dengan baik, karena di dukung oleh motivasi belajar siswa dalam meningkatkan hasil belajar. Bloom menyatakan bahwa hasil belajar adalah perolehan warga belajar setelah mengikuti proses belajar dan perolehan belajar meliputi tiga bidang kemampuan yaitu kognitif, afektif, dan psikomotorik. Kemampuan kognitif meliputi perolehan hasil belajar dengan tingkat pengetahuan, pemahaman, penerapan, analisis, sintesis, dan evaluasi. Kemampuan afektif meliputi jenjang penerimaan, pemberian respon, penilaian, pengorganisasian dan karakteristik. Sedangkan kemampuan psikomotorik meliputi tingkat persepsi kesiapan, gerakan terbimbing, gerakan biasa, dan gerakan komplek yang mensesuaikan pola gerakan dan kreativitas. Berdasarkan pemikiran di atas, penulis akan membahas lebih lanjut dalam bentuk penelitian tentang "Pengembangan Model Pembelajaran Kooperatif Tipe Tai Terhadap Hasil Belajar Siswa Mata Pelajaran IPS

\section{METODE PENELITIAN}

Metode penelitian ini mengunakan pendekatan penelitian dan pengembangan (Research and Development). Metode penelitian dan pengembangan merupakan metode yang digunakan untuk menghasilkan produk tertentu, dan menguji keefektifan produk tersebut (Sugiyono, 2013:407). Penelitian 
pengembangan yang diuraikan Sugiono (2013: 409) terdapat 10 tahap diantaranya (1) Potensi dan Masalah, (2) Pengumpulan Data, (3) Desain Produk, (4) Validasi Desain, (5) Revisi Desain, (6) Ujicoba Produk, (7) Revisi Desain, (8) Ujicoba Pemakaian, (9) Revisi Produk, (10) Produksi Akhir.

Terdapat sepuluh langkah prosedur pengembangan dalam penelitian research and development (R\&D) menurut Borg and Gall (1989:783-795), yaitu: (1) Research and Information Collecting; (2) Planning; (3) Develop Preliminary of Product; (4) Preliminary Field Testing; (5) Main Product Revision; (6) Main Field Test; (7) Operational Product Revision; (8) Operational Field Testing; (9) Final Product Revision; dan (10) Final Product

Tahap Perencanaan (planning) yang dilakukan dalam tahap ini sebagai berikut. Pertama adalah merancang ruang lingkup penelitian (define the scope) dengan materi pelajaran IPS Kelas 5 SDN 7 Kediri dengan pokok bahasan tentang sejarah para pahlawan yang dirangkaikan dengan pengenalan pahlawan kemerdekaan Republik Indonesia.

Kedua, mengidentifikasi karakteris- tik siswa (identify learner characteristic). Identifikasi yang lebih spesifik terhadap karakteristik siswa SDN 7 Kediri, dilakukan dengan membagikan in-strumen dalam rangka analisis kebutuhan ketika prasurvei di sekolah. Ketiga adalah menentukan dan mengumpulkan sumber- sumber (determine and collect resources) dari buku, jurnal, artikel, dan internet, sebagai referensi dalam menyusun bahan ajar IPS Kelas 5 SDN 7 Kediri. Keempat adalah melakukan yaitu melakukan diskusi dan wawancara dengan guru mata pelajaran IPS terkait metode pa saja yang sudah digunakan sebelumnya, dan teman sejawat dalam rangka membuat konsep awal tentang pengembangan metode TAI (Team Assited Individualization

Tahap desain (design), pada tahap ini aktivitas yang dilakukan berhubungan dengan mendesain sebuah model pembelajaran TAI (Team Assited Individualization. Yang terdiri dari langkah-langkah sebagai berikut. Pertama adalah melakukan analisis konsep dan materi8 yang akan diberikan. Kedua adalah membuat struktur pengembangan bahan ajar IPS Kelas 5 berupa menyusun flow- chart. Ketiga adalah mendeskripsikan prog 
ram pendahuluan. Keempat adalah menentukan bahan ajar apa yang digunakan dalam pengembangan model TAI (Team Assited Individualization

Tahap pengembangan (development) Pada tahap ini aktifitas yang dilakukan ter- dapat enam langkah sebagai berikut. Pertama adalah membuat bentuk model pembelajaran yang sudah ada disesuaikan dengan karakteritik siswa yang telah ditetapkan. Selanjutnya pengembang memberikan desain pengembangan model TAI (Team Assited Individualization) untuk diberikan masukan oleh TIM validasi model , ada beberapa yang harus dikembangkan dalam model pembelajaran tersebut, yaitu bahan ajar yang sesuai dengan karakteristik siswa dan penggunaan model tersebutsehingga menimbulkan adanya perubahan hasil belajar.

\section{Teknik Analisis Data}

Tingkat keefektifan model TAI (Team Assited Individualization) dapat dicari dengan membandingkan hasil perlakuan antar kedua kelompok. Apabila skor kelompok model TAI (Team Assited Individualization) lebih tinggi dibandingkan dengan kelompok metode lama di kelas berarti model TAI (Team Assited Individualization) lebih efektif dalam membangun karakter peserta didik dibandingkan dengan metode lama, begitu juga sebaliknya.

Hipotesisnya dirumuskan sebagai berikut:

Ho : Efektivitas model TAI (Team Assited Individualization) lebih kecil atau sama dengan dengan metode lama dalam meningkatkan hasil belajar IPS Siswa Sekolah Dasar.

Ha: Efektivitas model TAI (Team Assited Individualization) lebih baik dari metode lama dalam meningkatkan hasil belajar IPS siswa Sekolah Dasar . Ada dua tehnik data yang digunakan untuk mengelola data dihimpun dari hasil review dan uji coba pengembangan produk perangkat pembelajaran yaitu dengan menggunakan analisis deskriptif kualitatif dan analisis statistik deskriptif.

\section{a. Analisis Deskriptif Kualitatif}

Analisis deskriptif kualitatif digunakan untuk mengolah data dari hasil review ahli pembelajaran, ahli materi dan ahli media pembelajaran. Analisis informasi dari data kualitatif yang berupa 
masukan, tanggapan, kritik, saran, $P=\frac{\sum \mathrm{xi}}{\sum \mathrm{x}} \mathrm{x}$

perbaikan yang terdapat pada angket.

Hasil analisis ini kemudian digunakan sebagai dasar mereview produk pembelajaran.

\section{b. Analisis Statistik Deskriptif}

Tehnik analisis statistic deskriptif digunakan untuk mengolah data yang di peroleh melalui angket dalam bentuk analisis persentase.

Rumus yang di gunakan untuk Keterangan :

$\mathrm{P} \quad=$ Persentase keseluruhan subyek/komponen

$\mathrm{xi}=$ Jumlah persentase

keseluruhan Komponen

$\sum \mathrm{x}=$ Banyak Komponen

Dalam pengambilan keputusan merevisi produk, digunakan klasifikasi tingkat kelayakan kriteria produk, yaitu menghitung persentase dari masingmasing subyek adalah sebagai berikut:

Tabel 1. Konversi tingkat pencapaian dengan skala 5 yakni :

\begin{tabular}{|l|l|l|}
\hline $\begin{array}{l}\text { Tingkat } \\
\text { Pencapaian }\end{array}$ & Kualifikasi & Keterangan \\
\hline $90 \%-100 \%$ & Sangat & Sangat layak, tidak perlu direvisi \\
$75 \%-89 \%$ & baik & Layak, tidak perlu direvisi \\
$65 \%-74 \%$ & Baik & Cukup layak, perlu revisi Tidak \\
$55 \%-64 \%$ & Cukup & layak, perlu revisi \\
$0 \%-54 \%$ & baik & Sangat tidak layak, perlu revisi \\
& Cukup & \\
\hline & Kurang Cukup & \\
\hline
\end{tabular}


Keterangan tabel kriteria tingkat kelayakan yaitu:

a. Apabila paket pembelajaran yang diujicoban tersebut mencapai tingkat persentase $90 \%-100 \%$, maka paket pembelajaran tersebut tergolong kualifikasi sangat baik ( Sangat layak ).

b. Apabila paket pembelajaran yang diujicobakan mencapai tingkat persentase $75 \%$ - $89 \%$, maka paket pembelajaran tersebut tergolong kualifikasi baik (Layak).

c. Apabila paket pembelajaran yang diujicobakan mencapai tingkat persentase $65 \%$ - 74\%, maka paket pembelajaran tersebut tergolong kualifikasi cukup baik (Cukup layak).

d. Apabila paket pembelajaran yang diujicobakan mencapai tingkat persentase $55 \%$ - 64\%, maka paket pembelajaran tersebut tergolong kualifikasi cukup (tidak layak). e. Apabila paket pembelajaran yang diujicobakan mencapai tingkat persentase $0 \%$ - 54\%, maka paket pembelajaran tersebut tergolong kualifikasi kurang cukup (Sangat tidak layak).

Adapun produk model TAI (Team Assited Individualization) ini dikategorikan layak, apabila mencapai skor rata-rata antara 70\%-80\%. Selanjutnya dengan skor tersebut berarti produk metode model TAI (Team Assited Individualization) tersebut tidak perlu ada perbaikan/revisi dan dapat dikatakan layak untuk digunakan dalam proses pembelajaran.

\section{c. Analisis Hasil Belajar IPS Siswa SD}

Hasil belajar IPS siswa SD diberikan lima pilihan untuk melihat hasil belajar yang dikembangkan yaitu instrument yang berupa angket digunakan pada awal dan akhir proses pembelajaran.

Tabel 2. Kriteria keberhasilan proses pembelajaran

\begin{tabular}{|c|l|l|}
\hline No & Tingkat Keberhasilan & Predikat Keberhasilan \\
\hline 1 & $86-100 \%$ & Sangat Tinggi/ Sangat Layak \\
\hline 2 & $71-85 \%$ & Tinggi/Layak \\
\hline 3 & $56-70 \%$ & Sedang /Cukup Layak \\
\hline 4 & $41-55 \%$ & Rendah/Cukup Tidak Layak \\
\hline 5 & $<40 \%$ & $\begin{array}{l}\text { Sangat Rendah/Sangat tidak } \\
\text { Layak }\end{array}$ \\
\hline & Rentang Skor 15\% \\
\hline
\end{tabular}

Nilai rata-rata hasil belajar IPS ini dapat menggunakan rumus

$X=\sum x$

$\sum \mathrm{N}$

$\mathrm{X}=$ Nilai rata-rata

$\sum \mathrm{x}=$ Jumlah semua nilai siswa

$\sum \mathrm{N}=$ Jumlah siswa yang mengikuti tes

(Arikunto: 2015) 


\section{HASIL PENELITIAN DAN} PEMBAHASAN

Berdasarkan hasil penilaian dari seorang ahli pembelajaran terhadap RPP sebagaimana tercantum pada tabel sebelumnya di atas, hasil hitungan persentase diperoleh sebesar $99.90 \%$ setelah dikonversi menunjukkan bahwa perangkat pembelajran berupa RPP dalam kualifikasi sangat baik sehingga secara umum tidak perlu di revisi.

Tabel 3. Hasil Penilaian Ahli Pembelajaran Terhadap model TAI (Team Assited Individualization)

\begin{tabular}{|c|c|c|c|}
\hline $\begin{array}{c}\text { Jumlah Item } \\
\text { Pertanyaan }\end{array}$ & Skor & Frekuensi & Persentase \\
\hline \multirow{3}{*}{12} & 5 & 6 & 50.00 \\
\cline { 2 - 4 } & 4 & 3 & 25.00 \\
\cline { 2 - 4 } & 3 & 1 & 8.333 \\
\cline { 2 - 4 } & \multicolumn{2}{|c|}{ Jumlah } & $83.3 \%$ \\
\hline
\end{tabular}

Masukan, saran dan komentar ahli pembelajaran berkenaan dengan RPP yang menggunakan model TAI (Team
Assited Individualization) dapat memadai untuk dilakukan uji berikutnya.

Tabel 4. Data Hasil Uji coba Terbatas Produk model TAI (Team Assited Individualization) menggunakan Instrumen hasil belajar IPS.

\begin{tabular}{|c|c|c|c|}
\hline No & $\begin{array}{c}\text { Banyak } \\
\text { Responden }\end{array}$ & $\sum x$ & $\sum \mathrm{n}$ \\
\hline 1 & 1 & 84 & \multirow{10}{*}{10} \\
\hline 2 & 2 & 76 & \\
\hline 3 & 3 & 72 & \\
\hline 4 & 4 & 76 & \\
\hline 5 & 5 & 68 & \\
\hline 6 & 6 & 68 & \\
\hline 7 & 7 & 72 & \\
\hline 8 & 8 & 76 & \\
\hline 9 & 9 & 84 & \\
\hline 10 & 10 & 80 & \\
\hline & umlah & 756 & $75.6 \%$ \\
\hline
\end{tabular}

Berdasarkan penilaian / tabel kelayakan, maka model TAI tanggapan sebagaimana tercantum (Team Assited Individualization) dalam tabel 5.5 diketahui bahwa rata- berada dalam kualifikasi tinggi/layak rata persentase tingkat pencapaian dan tidak perlu direvisi.

model TAI (Team Assited

Individualization) sebesar $75.6 \%$ rerata tersebut bila dikonversikan dengan 
Tabel 5. Data Hasil Uji coba Lapangan Terhadap hasil Belajar IPS Siswa

\begin{tabular}{|c|c|c|c|}
\hline No. & $\begin{array}{c}\text { Nama } \\
\text { Responden }\end{array}$ & Pre test & Post-test \\
\hline 1 & A & 64 & 84 \\
\hline 2 & B & 68 & 92 \\
\hline 3 & $\mathrm{C}$ & 60 & 84 \\
\hline 4 & $\mathrm{D}$ & 64 & 88 \\
\hline 5 & $\mathrm{E}$ & 60 & 80 \\
\hline 6 & $\mathrm{~F}$ & 64 & 92 \\
\hline 7 & G & 60 & 88 \\
\hline 8 & $\mathrm{H}$ & 64 & 80 \\
\hline 9 & $\mathrm{I}$ & 60 & 88 \\
\hline 10 & $\mathrm{~J}$ & 64 & 84 \\
\hline 11 & $\mathrm{~K}$ & 60 & 88 \\
\hline 12 & $\mathrm{~L}$ & 64 & 92 \\
\hline 13 & $\mathrm{M}$ & 64 & 88 \\
\hline 14 & $\mathrm{~N}$ & 68 & 84 \\
\hline 15 & $\mathrm{O}$ & 68 & 88 \\
\hline 16 & $\mathrm{P}$ & 60 & 84 \\
\hline 17 & $Q$ & 68 & 96 \\
\hline 18 & $\mathrm{R}$ & 60 & 92 \\
\hline \multirow[t]{3}{*}{29} & $S$ & 60 & 88 \\
\hline & Jumlah & Jumlah & jumlah \\
\hline & 20 & $\begin{array}{l}\text { Rata-rata } \\
=\frac{1260}{20} \\
=62,5 \%\end{array}$ & $\begin{array}{l}\text { Rata-rata } \\
=\frac{1752}{20} \\
=87,6 \%\end{array}$ \\
\hline \multicolumn{2}{|c|}{ Kategori } & Cukup Baik & $\begin{array}{c}\text { Sangat } \\
\text { Baik }\end{array}$ \\
\hline
\end{tabular}

\section{KESIMPULAN}

Berdasarkan hasil uji coba lapangan sebagaimana tercantum pada tabel 5.8 di atas, skor yang diperoleh terhadap 20 siswa adalah sangat baik. Rerata yang persentase diperoleh sebesar $87.6 \%$ setelah dikonversikan dengan tabel konversi diketahui bahwa dengan menggunakan model TAI (Team Assited Individualization) berada dalam kualifikasi sangat baik hasil belajar siswa kelas 5 pada mata pelajaran IPS di Sekolah Dasar.

Berdasarkan hasil penelitian dapat disimpulkan bahwa dalam penelitian dan pengembangan adalah sebagai berikut :
1. Berdasarkan hasil validasi para ahli bahwa produk layak untuk digunakan

2. Berdasarkan hasil ujicoba lapangan produk berupa RPP dengan menggunakan model TAI (Team Assited Individualization) dapat meningkatkan hasil belajar IPS siswa Sekolah Dasar.

Untuk Meningkatkan kreativitas guru dalam mengembangkan RPP dan media pembelajaran di sekolah sehingga dapat menghasilkan pembelajaran yang PAIKEM (Pembelajaran yang Aktif, Interaktif, Kreatif, efektif dan menyenangkan). 


\section{DAFTAR PUSTAKA}

Anwar dan Hendra. 2011. Hasil Belajar. Bandung : Alfabeta

Arikunto, S. (2006). Prosedur penelitian suatu pendekatan praktik, ed revisiVI. Pener- bit PT Rineka Cipta: Jakarta.

Brahim, Theresia. 2012. Bahan ajar Tentang Teori, Model,Pendekatan, Starategi, Metode, Tipe, Tehnik, Taktik, Media dan Belajar. Jakarta : Universitas Negeri Jakarta.

Bloom, Benyamin S. 1959. Taxonomi of Objectives : The Clasification of Education Goals. New York : Longman Inc

Djaali dan Mudjiono, 2008. Pengukuran dalam Bidang Pendidikan. Jakarta : Program Pascasarjana Universitas Negeri Jakarta.

Depdiknas. (2008). Panduan pengembahan bahan ajar dan media. Jakarta: Direk- torat Jenderal Manajemen Pendidikan Dasar dan Menengah.

Gagne, Robert and Leslie J. Briggs. 2005. Prinsiples of Instructional Design. New York : Holt Rinehart and Winston.

Hamalik, oemar. 2009. Proses Belajar Mengajar. Jakarta : PT Bumi Aksara.

Lif Amri Koiru. 2012. Factor-faktor yang Mempengaruhi Hasil
Belajar. Yogyakarta : Bumi aksara.

Jurnal Pendidikan Dasar. 2012. Universitas Negeri Jakarta : PT Bumi Timur Jaya.

Jamaris, Martini. 2010. Orientasi Baru dalam Psikologi Pendidikan. Jakarta Pusat : Yayasan Penamas Murni 